\title{
Slave networks in Menander ${ }^{1}$
}

\author{
Eftychia BATHRELLOU \\ St John's College, Oxford
}

Much recent and current scholarship on the representation of slavery in Greek literature, and in Attic drama in particular, ${ }^{2}$ whatever its specific agenda, ultimately revolves around the following question: Do the literary works under examination criticize, or somehow undermine or question, slavery, or do they ultimately legitimatize it and justify its acceptance? The scholarly answers to this question have, despite their apparent variety, been in essence insistently similar: namely, that, although signs of criticism cap sometimes be detected, slavery was not condemned in Attic drama and the surviving dramatic works, each in different ways and to different degrees, ultimately contributed to slavery's continued acceptance and justification. ${ }^{3}$

\footnotetext{
${ }^{1}$ I would like to thank the organizers of the conference 'Drama and Democracy from Ancient Times till the Present Day', especially Professor Ali Moein and Dr Adel ElNahas, for giving me the invaluable opportunity to come to Cairo in this conjuncture and be a part of this conference. This paper has been much inspired by the work of Kostals Vlassopoulos, who, of course, should not be held responsible for the opinions expressed here. I am also indebted to Timothy Duff-; for his comments and help. Any mistakes and other shortcomings are my own responsibility.

${ }^{2}$ The bibliography is substantial. The following list focuses only on Attic drama and is extremely selective: Stefanis 1980, Hall 1997, Rabinowitz 1998, Gregory 2002, Ebbott 2005, Zimmermann 2005, Hunt 2011, Nikolsky 2011; cf. also Fitzgerald 2000, McCarthy 2000 (both mainly on Roman material, but full of helpful insights). Specifically on Menander, see below.

${ }^{3}$ For some indicative scholarly work of this type on Menander, see, e.g.: Wiles 1988, Krieter-Spiro 1997, Hunt 2011, esp. 30-32. Cf. Proffitt 2011, who reaches a different conclusion. However, her paper is to an extent marred by factual inaccuracies: for example, pace Proffitt 2011, 156, 160, 167-68, it is not certain that Onesimos is manumitted at the end of the Epitrepontes.
} 


\section{Slave networks in Menander}

HoweverTo my mind, although our understanding of individual works and dramatists has been much enhanced by scholarship motivated by the question mentioned above, there are limitations in its potential-there is something doubly disappointing in its conclusion. First, The first problem is that such an approach inevitably leads to an impasse: after we have examined how slavery is explored and ultimately reinforced in each surviving tragedy and comedy, what will there be left to do? By this I mean: What questions will we then be able to ask? Second, the conclusions reached through such an approach, although important and correct, The second problem is that this conclusion-actually tells us nothing about the slaves; theyit speaks only about the attitudes of the free towards them.

One might reasonably argue, and many scholars have already done so, that the nature of our evidence does not allow us to recover the experiences of the enslaved. This is to a great extent correct. Our evidence is biased, especially since none of the surviving literary works were written by slaves or for slaves. ${ }^{4}$ But, when we only ask questions regarding literature's portrayal of the attitudes of the free towards the slaves, do we not-we actually reproduce this bias - or, at best, do little to mitigate it? If we are not able to recover the experiences of the enslaved, ought we not, at least, to use the evidence in order to try to imagine possible experiences? ${ }^{5}$

Some ancient historians, it is true, have looked at Attic drama in order to reconstruct the experiences of the enslaved. However, they tend to focus mainly on one aspect of these experiences: namely, the representations in the plays of the relationship between the enslaved and their masters. In practice, this inevitably results in exploring slavery as the extreme exploitation, victimization and dehumanization of the slave by the master. For example, attention is paid to the punishments given to the enslaved by the free, to the precariousness of the life of the enslaved, to

\footnotetext{
${ }^{4}$ On this see, e.g., Fisher 1993, 71, Fitzgerald 2000, 2-3.

5 For 'empathetic imagination' as a valid and useful tool for reconstructing the past, see Hopkins 1993.
} 


\section{Eftychia BATHRELLOU}

their social isolation and uprooting, their 'social death', as it has been put aptly by the historical sociologist Orlando Patterson, and to their immersion in the culture and their assumption of the values of the slave-owners. ${ }^{6}$ All this work is extremely important, and brings to the fore the brutality of slavery. But, once more, the masters loom large; and the larger the masters loom, the more the slaves fade away. In a way then, our scholarly practices unwittingly but, to my mind, chillingly reproduce (at a different level, of course) the disempowerment and dehumanization induced by slavery itself.

Instead, we ought to follow the example of some historians of modern slavery and of a few ancient historians and try to ask different questions:- questions that will allow us to place in the centre of our field of vision the slaves themselves - and not only in relation to their masters. ${ }^{7}$ Such questions will not of course magically make the slaves transparent to us. Since no slave literature has survived from antiquity, we will still be seeing the slaves through the eyes of the slave-owners. But, at least ${ }_{2}$ thils time we will be trying to imagine possibilities regarding their experience of slavery - not that of their masters.

The question I would like to try out in this paper in relation to Menander is the following: How are slaves represented as behaving towards each other in Menander? More specifically: Are they represented as cooperating with each other, in order to improve their lives or, even, escape their slavery? ${ }^{8}$ Are they represented as trying to form social networks of encouragement, support or, even, resistance against their masters or their condition?

In this paper, I give a very brief and rather superficial overview, rather than exploring every passage in all its ramifications. Similarly, I will

${ }^{6}$ For indicative scholarship of this type on Menander, see, e.g., Cox 2002; cf. McKeown 2011, 159-65. For slavery as social death, see Patterson 1982.

${ }^{7}$ For some indicative work, see, e.g.: Johnson 2003, Geary - Vlassopoulos 2009.

${ }^{8}$ I hope to explore the opposite tendency, namely representations of antagonism among slaves, elsewhere. 


\section{Slave networks in Menander}

not be able here to go a step further and try to assess the overall impact such representations would have had on Menander's contemporary audience. But I hope to make some suggestions and to provide some of the groundwork which can be used as a starting point for such an assessment in the future.

Let us start with Simiche, the old nurse in the Dyskolos. From her very first mention in the play, Simiche, who is the only slave of the misanthropic Knemon and nurse of his daughter, is presented as a helpless and terrorized old woman. We first hear of her from Knemon's daughter Iif Knemon, she says, finds out that Simiche has accidentally dropped the bucket in the well, he will 'beat her to death'. ${ }^{9}$ When we first see Simiche on stage, our impression of her being utterly terrorized by her peevish master is confirmed. She is coming out of Knemon's house in utter despair, in order to escape Knemon's rage. Her words reverberate with terror (see,

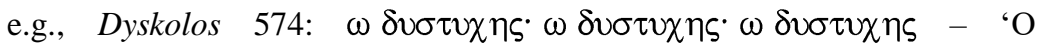
wretched me! O wretched me! O wretched me!'). However, when Knemon tells her that he plans to tie her to a rope and let her down the well, so that she might fetch the bucket and the mattock she has dropped there, Simiche thinks of a port of call: her neighbour and fellow slave Daos (594: $\tau o \nu \Delta \alpha O \nu \varepsilon \kappa \tau \omega \nu \gamma \varepsilon \iota \tau ం \nu \omega \nu \varepsilon \gamma \omega[\kappa \alpha \lambda] \omega-$ 'I will [shout for] Daos, from next door'). At this, Knemon explodes. 'You will shout for Daos, will you? You have ruined [me], you impious womanheathen! Do you hear me? Get inside, quickly!', he retorts. ${ }^{10}$

Knemon's reaction makes it clear that he finds Simiche's idea to ask for the help of Daos insolent and completely unacceptable. This is why he

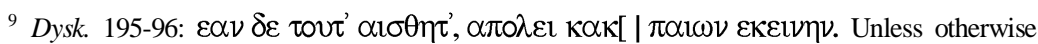
indicated, text and translations (occasionally modified) are from the Loeb edition of Menander by W. G. Arnott (vol. 1 1979, vol. 2 1996, vol. 3 2000).

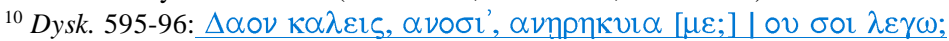

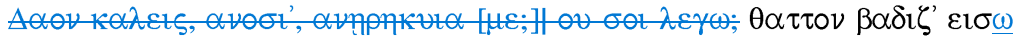

$\therefore$

Commented [E1]: I just moved the Greek a bit in the footnote, so that it looks nicer.

Commented [E2]: Above, there is usually slightly more space between the last line of one paragraph and the first line of the next. It would look nicer if it was the same throughout the document/book. 


\section{Eftychia BATHRELLOU}

decides to go down the well himself (Dyskolos 598-99), which will cause his own downfall (literally as well as metaphorically) and the play's happy resolution. What is important for our purposes here is that even the helpless old Simiche, in the face of her master's strict anti-social and self-isolating policy, has built for herself a network of support. Moreover, dDifferent to what scholars argue happens in some Attic drama, where slave initiative is presented as transgressive and dangerous, ${ }^{11}$ here we are clearly meant to side with Simiche, not Knemon, and to see her initiative to ask for help as normal and paradigmatic, in contrast to the unsociability of her master.

If this example from the Dyskolos shows slaves from neighbouring houses as developing relationships of support, the Heros provides an example of relationships at the level of the deme (Heros 21-24).

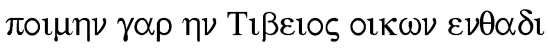

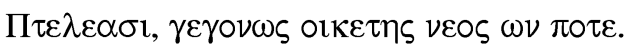

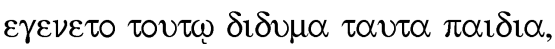
$\omega \varsigma \varepsilon \lambda \varepsilon \gamma \varepsilon v$ avtos...

You see, there was a shepherd living here in Ptelea, whohe ha'd been a slave when young,

Tibeios. He, who'd had got these twin children that's that's what he himself used to say...

This is in a brief reference, and so it is not clear how close a relationship Daos, who is a household slave and is the speaker here, had with the shepherd Tibeios. What is clear, however, is that they were close enough for Daos to have heard Tibeios, on more than one occasion (notice the imperfect tense of $\varepsilon \lambda \varepsilon \gamma \varepsilon v)$, talking about his twin children, or, at least, to have heard from others of Tibeios' talking about his children. The picture

11 See, e.g., Hall 1997, 113-18 (on tragedy). Cf. Krieter-Spiro 1997, 111-12, who highlights instances in Menander where the initiative of slaves exacerbates the problems of their masters.

Commented [E3]: Again, there is no space between the 2 paragraphs here.

Commented [E4]: There is no gap below this, but there is a big gap beneath the passage (i.e. before 'This is in a brief reference...') It would look nicer if there was a small gap BOTH above and below the quotation. 


\section{Slave networks in Menander}

built is, at the minimum, one of acquaintances who live in the same locality and share with each other information about themselves. ${ }^{12}$

We should note here something that we will observe in other passages too: namely, that the impression created by Daos' words is not necessarily one of an exclusive circle of slaves only. In fact, strictly speaking, it is most likely that Tibeios would have been imagined by the audience as having already been manumitted when Daos heard him speaking about his children. ${ }^{13}$ Daos' words allow for local people of a variety of statuses -including slaves, like Daos, ex-slaves, like Tibeios, but also other metics and, why not?, citizens too- to be exchanging news and talking to each other about their lives. ${ }^{14}$

But the networks which slaves in Menander build and in which they participate are not always restricted by locality. In the Epitrepontes, Syriskos, an independently living charcoal burner, ${ }^{15}$ who resides in the countryside and, as is to be expected in his profession, works in the woods (Epitr. 257-59; cf. 242), casually announces that he is popping to the city, in order to find out how he should deal with the new developments: namely that the foundling he had wanted to raise as his own child might now prove to be the illegitimate son of a wealthy Athenian citizen (Epitr. 462-63).

${ }^{12}$ It should perhaps be noted, for what it is worth, that Ptelea, the deme where the play is set (1. 22), must have been a rather small deme. See Traill 1975, 70.

${ }^{13}$ Notice $v \varepsilon \circ \zeta \omega \nu \pi 0 \tau \varepsilon$ at 1. 22. Tibeios, who would most likely have been imagined as older than Daos (since Daos is in love and wants to live with Tibeios' daughter), has already died at this point in the play (see 1l. 30, 32).

${ }^{14}$ See, e.g., Vlassopoulos 2007a, 2007b, 2009 (cf. also Vlassopoulos 2010, 2011), who draws attention to the evidence for interactions on equal footing among people of various statuses and backgrounds in classical Athens.

15 On slaves living independently in classical Athens, see Perotti 1974, Osborne 1991, especially 244-46, Kazakévich 2008. Although I do not find her conclusions persuasive, Kazakévich rightly highlights the complexities of the ancient terminology and correctly points out that not all independently living slaves would necessarily have had the same position in the system of production (see especially pp. 356,358 ).
Commented [E5]: From here onwards, in the footnotes, the first line of the footnote is more to the left than the other ones. It was different in the previous footnotes. It would look nicer if one policy was followed throughout. 


\section{Eftychia BATHRELLOU}

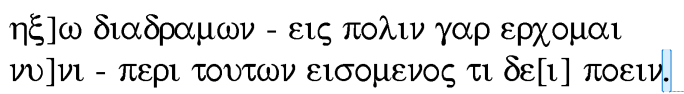

I have an errand to run, but [I will be back]. I'm off to town right now - to see what needs to be done about this. ${ }^{16}$
Commented [E6]: Elsewhere, there was no gap between the Greek and the translation (see for example p. 5, 10). It would look nicer if one policy was followed throughout.

We might imagine him going to the city, perhaps to the market, to find his friends who work at the workshops or trade at a stall, in order to ask for their advice. And, as in the case of Daos' words in the Heros, Syriskos' announcement here does not exclude the possibility that some of his friends in the city might not have been slaves, but, for example, metics or, even, Athenian citizens.

However, Syriskos' 'city circle' is not the norm in what has survived of Menander. Most social networks of slaves are set in the countryside. Daos' and Syriskos' narration of the background to their dispute in Act II of the Epitrepontes is a very good illustration of this. ${ }^{17}$ It is in the woods, where they both work, Daos as an independently living shepherd, Syriskos, as we saw, as an independently living charcoal burner, that they meet each other. When Syriskos sees Daos looking glum, he is not indifferent but offers a friendly ear. Daos finds emotional support, and is relieved from his anxiety regarding the baby he had found but is now reluctant to raise, because Syriskos offers to raise it himself. In the woods, Syriskos and Daos are not the only ones who are acquainted with each other. We learn that there are other shepherds too, and that Daos has talked about the baby to at least one of them. Syriskos too has independently

${ }^{16}$ Translation: Ireland 2010.

${ }^{17}$ See, for example, Epitr. 256-61 (Daos speaking): 'Next morning I was with my sheep again, and this manhe (i.e. Syriskos) came -he's a charcoal burner- to that same place, to saw some stumps there. We'd become acquainted earlier

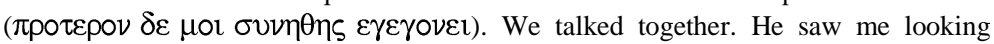
glum. "Why's Daos fraught?" he asked...'. See also, e.g., Epitr. 299-301 (Syriskos speaking): '...A shepherd, one he (i.e. Daos) had talked to and who works with him

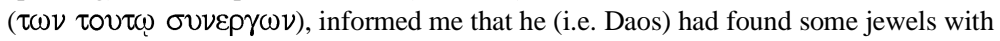
the baby...'? 


\section{Slave networks in Menander}

spoken to that other shepherd. Daos' and Syriskos' references then build for us the picture of a network of co-workers, shepherds and charcoal burners, in the woods. They greet each other, they exchange information, they share their problems, they help each other.

Wealthy slave-owners are clearly not part of this network. But, as in the two passages discussed above, no particular attention is drawn to the workers' precise status. The men are referred to as 'fellow acquaintances'

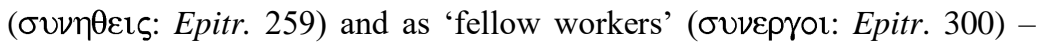
not as, for example, 'fellow slaves' ( $\sigma v \nu \delta \circ v \lambda \circ \mathrm{l}$ : cf. Perinthia 5, on which below). This network too has, then, the potential to cut across free and nonfree statuses. In the woods, the common denominator is labour - not status.

Another type of network that some slaves in Menander try to build is that of kin. ${ }^{18}$ In the Heros, Tibeios, a slave shepherd, ${ }^{19}$ raises the twins who have been abandoned or given away by their mother (Heros 23-24). (The play does not survive in its entirety, so we cannot be certain.) In the same play, Daos, a household slave, is in love with a girl who works for his mistress, and wants to set up family with her (Heros 15, 18-19, 41-44). In the Epitrepontes, Daos, as we saw, initially takes on a foundling to raise. In the same play, Syriskos has a wife. They have had their own baby but it died, and they jump at the opportunity of raising the baby found by Daos. The insistence with which Syriskos begs Daos to give him the baby to raise illustrates well his desire to have a family.

Then, right away, [...] he (i.e. Syriskos) started pleading, adding a 'Bless you, Daos' to each phrase. He said, 'Give me

${ }^{18}$ On family-building by slaves in archaic and classical Greece, see now Schmitz 2012; also, e.g., Klees 1998, 155-75, Golden 2011, especially 143-46.

19 Although it is made clear in the play that at some point in his life Tibeios was manumitted (see 1. 22), it is nowhere specified whether this had happened before or after he took on the twins (pace, e.g., Arnott 1996, 4, who takes it for granted that the manumission took place first). On Tibeios' status when he took on the children, see also Schmitz 2012, 91-92. 


\section{Eftychia BATHRELLOU}

the baby, as you hope for luck and freedom

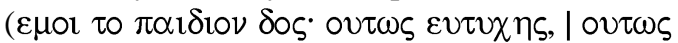

$\varepsilon \lambda \varepsilon v \theta \varepsilon \rho \circ \varsigma)$. I have a wife, you see, and our baby died at birth.' [...] He spent the whole day pleading, begged and tried to win me round. I said yes [...], off he went, with blessings on his lips galore. He gripped my hands and kissed them. ${ }^{20}$

When discussing some of these passages, scholars tend to emphasize that the slaves' efforts to surpass their 'social death' and create families prove in the end to have been in vain. ${ }^{21}$ Because the plays are centred around the needs and interests of citizens, Daos in the Heros will not in the end marry the girl he loves, since she is an Athenian citizen; nor will Syriskos and his wife raise the foundling, since the baby too is the son of citizens. That the plays' main interest is not in the slaves, but in the fate of the citizens and the preservation and continuation of their households is undoubtedly true. But not all attempts by slaves to raise a family are doomed to fail in Menander. Although he dies in extreme poverty and in great debts, Tibeios in the Heros was able to raise the twins and in the end was buried by his son Gorgias - with the care and respect, we might assume, that he as a father would have wished for and expected from his son. ${ }^{22}$ Although the child is taken away from them, Syriskos and his wife remain a couple at the end of the Epitrepontes, and they might have another child of their own one day.

Slaves in Menander are also presented as supporting each other even in extremely restrictive circumstances. In the Sikyonioi, the divinity who delivers the prologue explains how Philoumene, the female protagonist of

${ }^{20}$ Selections from Epitr. 263-74: Daos speaking.

${ }^{21}$ See, for example, Lape 2004, 100-101; also, e.g., Arnott- 1996, 5-6, Krieter-Spiro 199ł, 122.

${ }^{22}$ Heros 32-34: That Gorgias borrowed money and got his sister and himself into eveh greater debt in order to arrange for Tibeios' funeral and the customary burial rites creates the impression that Tibeios was not merely put in a grave but was buried with respect. For the connection between having children and being provided with a funeral, see, e.g., Isaios 2.10 . 


\section{Slave networks in Menander}

the play, ended up a slave in Asia Minor, although she was the daughter of an Athenian citizen. ${ }^{23}$ When Philoumene was only a little girl, pirates captured her and her father's slave Dromon from the coast of Attica. The pirates took Philoumene and Dromon across the Aegean, to Karia, and put them on the slave market at Mylasa, where they were bought by an army officer. Immediately after this, and while Philoumene and Dromon were still at the slave-dealer's stall, another slave, who happened to have been placed near them by the slave-dealer, reassured Dromon that the man who had just bought them was good, reputable and wealthy. His words are reported in direct speech.

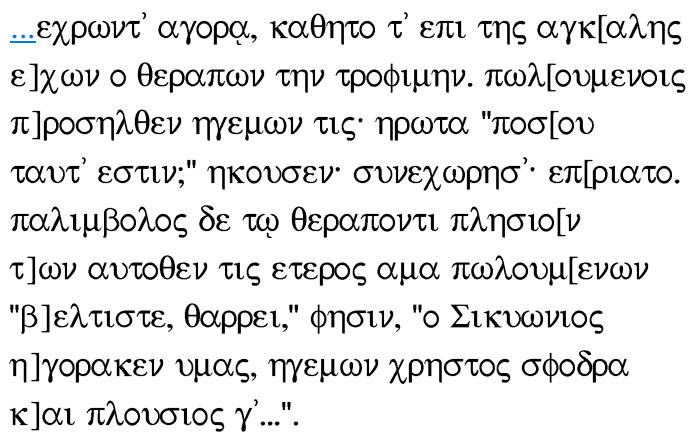

They (i.e. the pirates) made use of the market. The slave sat holding his young mistress on one arm. [They were] for sale. An officer approached. He asked 'How much are they?' He was informed, agreed, and [bought] them. Near the slave another of the men on sale there (he'd been through this hoop before) said 'Sir, cheer up! The man from Sikyon has bought you - a very fine officer, and wealthy too'. ${ }^{24}$

${ }^{23}$ Sik. 1-24. On the identity of this divinity, see Blanchard 2009, xlviii-xlix, with earlier bibliography.

${ }^{24}$ Sik. 7-15. 


\section{Eftychia BATHRELLOU}

The papyrus breaks off roughly at this point, but it is most likely that the dramatic point of reporting the words of the other slave is to present the buyer of Dromon and Philoumene, who is either the play's male protagonist or his foster father, in the best possible light. But we would lose much if we regarded this report of the slave's words merely as a means of presenting the buyer and perhaps of adding vividness to the narrative. Fot; the passage presents the slaves as managing to preserve their humanity, dignity and self-respect in the most dehumanizing circumstances possible, in circumstances which literally turn human beings into commoditip products. (Note that Dromon and the girl are referred to merely as $\tau \alpha u \tau \alpha$ by the prospective buyer: 1. 10.) The slave placed next to Dromon at the slave market, the $\pi \alpha \lambda \mu \mu \beta 0 \lambda \circ \varsigma$, as the divinity who delivers the prologue specifies, that is 'the one who has been put to the market more than once', not only offers information and reassurance to Dromon, but addresses him with utmost respect: $\beta \varepsilon \lambda \tau \imath \sigma \tau \varepsilon .^{25}$

Earlier scholars have found this very respectful address incongruous, addressed as it is to a slave (Gomme - Sandbach 1973, 638). And, one might argue, the fact that the slave who utters it is specifically presented as 'having been put to the market before' ( $\pi \alpha \lambda \mu \mu \beta 0 \lambda \circ \varsigma)$ would have coloured his words negatively. Menander's contemporary audience, who might have bought their own slaves at a slave market and have seen, as slave-owners in the New World also did, negative implications in being a $\pi \alpha \lambda \mu \mu \beta 0 \lambda \circ \varsigma$, might have not been able to show much sympathy for this character. ${ }^{26}$ Even so: for us today this passage illustrates what our modern discourses about the dehumanization induced by slavery sometimes do not

\footnotetext{
${ }^{25}$ On this address, see Dickey 1996, 139.

${ }^{26}$ For the negative implications of a slave's being put to the market more than once, see, e.g., Hypereides fr. 139a Jensen. For examples from the New World, see Johnson 1999, 124.
} 


\section{Slave networks in Menander}

allow us to see: namely that, to use Paul Millett's astute formulation, 'humanity within slavery is the prerogative of the slave'. ${ }^{27}$

Other forms of cooperation and support also appear in the plays. For example, in Act III of the Epitrepontes, Onesimos, a chief household slave, and Habrotonon, a slave harpist and hetaira, cooperate in order to achieve their freedom. ${ }^{28}$ They hope to do so by trying to restore an abandoned baby, who is about to be raised as a slave, to its rightful parents, who, they rightly suspect, are two Athenian citizens. Thus, in this play, the slaves' collective efforts to achieve freedom-absolutely_coincide with their efforts to restore the citizens' household. The interests of slave and free, of citizens and noncitizens, and the process of achieving them, have become not only interdependent but also identical.

Such harmonious coincidence of interests, however, is not always the case. In the Georgos, for example, we learn from Daos, a chief household slave, that the slaves of the farmer Kleainetos, who lives in the countryside, literally let Kleainetos rot, when he cut his leg while digging in the fields: his leg gangrened and he would have died if it were not for a poor but decent citizen young man (Georgos 46-62).

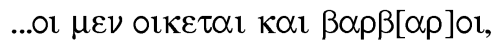

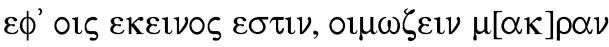

$$
\begin{aligned}
& \varepsilon \lambda[\varepsilon] \gamma \circ \nu \alpha \pi \alpha \nu \tau \varepsilon \zeta . . .
\end{aligned}
$$

${ }^{27}$ Millett 2007, 208. See also Johnson 2003.

${ }^{28}$ See, e.g., Epitr. 497-98, 543-44, 549-50, 553-54. It should perhaps be noted that this is not presented as their primary goal. In any case, there is no reason to assume, as many modern scholars have done, that Habrotonon's and Onesimos' wish to achieve their freedom would have cast them in a negative light for Menander's contemporary audience: see Brown 1990, 265-66, and below. 


\section{Eftychia BATHRELLOU}

The barbarian slaves in whose hands he (i.e. Kleainetos) found himself all consigned him to perdition... ${ }^{29}$

It is possibleeasy to read this example as confirming the standard scholarly understanding of the representations of slaves in Greek literature: namely, that the way slaves are represented in literature ultimately reassures the masters and reinforces their ideologies. For example, the passage might be seen as playing out the fears of the slave-owners that, if they, like Kleainetos, who has no family of his own, are isolated and do not have their own family around them to support them, they might be harmed by their slaves. ${ }^{30}$ And, such a reading would go on, in this passage from the Georgos such fears are played out only to be allayed in the end. The threatening potential of the slaves' inimical behaviour towards their master is neutralized both by the plot and by the narrative. Specifically, the intervention of the citizen youth will save Kleainetos' life, who has learnt his lesson and the first thing he will decide to do after he gets better is to break his isolation and arrange to get married (Georgos 64-7ㅌ). And, bł having the slaves' act narrated by another slave and in clear disapproval, the narrative presents the slaves' decision not to help their master in as negative a light as possible. Such a reading of the passage would, I thinl, be valid and illuminating. However, the fact that the slaves' collective action against their owner is thus thwarted in this play does not annul the fact that the play does air the possibility for such action. ${ }^{31}$

This instance in the Georgos, of the farmer's agricultural slaves' deciding not to care for him when he needs them most, is the only example of collective slave sabotage against a master in what has survived of Menander. There are, however, examples of incitement by a slave to

${ }^{29}$ Georgos 56-58. For the translation of 1. 56, seeI have used__Austin 2004, 85 (see-also Gomme - Sandbach 1973, 114) - not Arnott.

${ }^{30}$ For such fears, see, e.g.. Plato, Republic 578d-e, with Thalmann 2007. Also, for example, Demosthenes 48.14-16.

${ }^{31}$ Cf. McKeown 2011, 163, who somewhat downplays the significance of this passage. I 


\section{Slave networks in Menander}

individual disobedience and sabotage. Due to space restrictions, I will not discuss them here. I will only briefly draw attention to the fact that in one of these examples, the finale of the Dyskolos, the slaves not only take up the initiative to torment a citizen, but their actions against him are clearly represented as the agents of comic justice in the play. ${ }^{32}$

My final example is the only surviving scene of the Perinthia (Per. 1-23). The papyrus which preserves this scene is severely mutilated, so we cannot be sure about all the details. However, it seems that Daos, apparently the chief household slave of the citizen Laches, has sought sanctuary at an altar, in order to escape punishment. Laches, probably in order to force Daos to leave the altar so that he can punish him, has ordered his other slaves to light a big bonfire around Daos. The papyrus breaks off shortly after that, so we do not know what exactly happened, but it remains clear that Laches' other slaves bring on stage brushwood and place it around Daos, for Laches to light the bonfire. In this moment of extreme danger, Daos does not address Laches, to beg him to stop. Instead, he turns to his fellow slaves (Per. 3-7). ${ }^{33}$

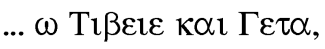

$\varepsilon \pi \varepsilon \imath \tau \alpha \kappa \alpha \tau \alpha \kappa \alpha v \sigma \varepsilon \imath \mu^{\prime} ; \alpha \phi \varepsilon \imath \eta \tau^{\prime} \alpha \nu, \Gamma \varepsilon \tau \alpha$,

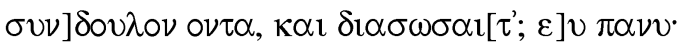

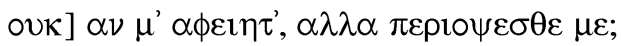

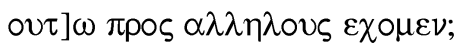

Tibeios and Getas,

will he then burn me alive? Please, let me go, Getas

-your [fellow] slave- and save me? Very [well]. -

Will you [not] let me go, but? And turn your back on me?

${ }^{32}$ Apart from the finale of the Dyskolos (11. 885-964), the other examples are: Aspis 226-30 and 238-41, Dysk. 630-32. I hope to be able to discuss them elsewhere.

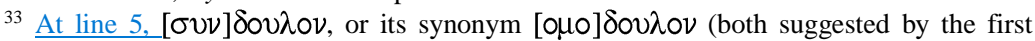
editors of the papyrus which has preserved this scene: P. Oxy. 855), is an almost certain supplement. See Gomme - Sandbach 1973, 536-37. 


\section{Eftychia BATHRELLOU}

Is [that the way] we treat each other?

Another surviving fragment from this play (fr. 3; cf. 11. 13-15) suggests that Daos was portrayed in the play as a scheming slave, keen to trick his master. In the light of this, one could treat this scene, with Daos about to be set on fire put up in flames by his master, as an indication that even the 'clever slave' in Menander can ultimately be outwitted by his master: it is the slave-owner, not the slave, who has the last word, and hence the play reinforces the ideology of the slave-owners. Such a reading is possible and might indeed be valid. ${ }^{34}$ However, what it would miss because of its focus on the free is at least equally important: namely, that the words of Daos, who expects from his fellow slaves to disobey their master and protect him precisely because they are all fellow slaves, express a perception that he and his fellow slaves constitute a group with common interests, which not only excludes but also stands in opposition to their master. In other words, Daos' words are a clear expression of group, if not class, consciousness. ${ }^{35}$

To conclude: I have offered an incomplete and all-too-superficial overview of representations of slave solidarities in Menander. Despite the lack of systematic analysis, I hope that my examples have given an indication of the wealth of possible vistas Menander's plays can open for the study of Greek slavery, if we put the slaves, rather than the free, at the centre of our attention.

${ }^{34}$ Most of the Perinthia has not survived, and we cannot tell with certainty what precisely happened at the end. For the evidence and some suggestions, see Gomme - Sandbach 1973, 533-35.

35 Whether slaves in classical Athens might be regarded as a class or not is a much disputed issue. For a recent contribution to the debate, see Alston (2011), with earlier bibliography. 


\section{Slave networks in Menander}

Works cited:

Alston, R. 2011. Rereading Ancient Slavery. In Alston - Hall - Proffitt 2011, 1-33.

Alston, R. - Hall, E. - Proffitt, L. (eds). 2011. Reading Ancient Slavery. London - New York.

Arnott, W. G. 1979. Menander. Vol. 1. Cambridge, Mass.

Arnott, W. G. 1996. Menander. Vol. 2. Cambridge, Mass.

Arnott, W. G. 2000. Menander. Vol. 3. Cambridge, Mass.

Austin, C. 2004. Le papyrus de Genève du Campagnard. In Bastianini, G. Casanova, A. (eds). Menandro: Cent'anni di papiri, 79-94. Florence.

Blanchard, A. 2009. Ménandre: Les Sicyoniens. Paris.

Bradley, K. - Cartledge, P. (eds). 2011. The Cambridge World History of Slavery. Vol. 1: The Ancient Mediterranean World. Cambridge.

Brown, P. G. McC. 1990. Plots and Prostitutes in Greek New Comedy. Papers of the Liverpool Latin Seminar 6: 241-66. Reprinted (by mistake under the title of another work of Brown) in Segal, E. (ed.). Oxford Readings in Menander, Plautus, and Terence, 53-64. Oxford. 2001.

Cox, C. 2002. Assuming the Master's Values: The Slave's Response to Punishment and Neglect in Menander. Mouseion 2: 23-38.

Dickey, E. 1996. Greek Forms of Address: From Herodotus to Lucian. Oxford.

Ebbott, M. 2005. Marginal Figures. In Gregory, J. (ed.). A Companion to Greek Tragedy, 366-76. Oxford.

Fisher, N. R. E. 1993. Slavery in Classical Greece. Bristol.

Fitzgerald, W. 2000. Slavery and the Roman Literary Imagination. Cambridge. 


\section{Eftychia BATHRELLOU}

Geary, D. - Vlassopoulos, K. (eds). 2009. Slavery, Citizenship and the State in Classical Antiquity and the Modern Americas. European Review of History 16.3 (special issue): 295-436.

Golden, M. 2011. Slavery and the Greek Family. In Bradley - Cartledge 2011, 134-52.

Gomme, A. W. - Sandbach, F. H. 1973. Menander: A Commentary. Oxford.

Gregory, J. 2002. Euripides as Social Critic. $G \& R$ 49: 145-62.

Hall, E. 1997. The Sociology of Athenian Tragedy. In Easterling $2_{2}=$ P. B. (ed.). The Cambridge Companion to Greek Tragedy, 93-126. Cambridge.

Hopkins, K. 1993. Novel Evidence for Roman Slavery. Past and Present 138: 3-27.

Hunt, P. 2011. Slaves in Greek Literary Culture. In Bradley - Cartledge 2011, 22-47.

Ireland, S. 2010. Menander: The Shield and The Arbitration. Oxford.

Johnson, W. 1999. Soul by Soul: Life Inside the Antebellum Slave Market. Cambridge, Mass.

Johnson, W. 2003. On Agency. Journal of Social History 37.1: 113-24.

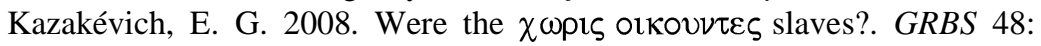
343-80. Edited by Deborah Kamen. Originally published in Russian in VDI 73.3 (1960): 23-42.

Klees, H. 1998. Sklavenleben im klassischen Griechenland. Stuttgart.

Formatted: Font: Italic

Krieter-Spiro, M. 1997. Sklaven, Köche und Hetären: Das Dienstpersonal bei Menander - Stellung, Rolle, Komik und Sprache. Stuttgart Leipzig.

Lape, S. 2004. Reproducing Athens: Menander's Comedy, Democratic Culture, and the Hellenistic City. Princeton - Oxford.

McCarthy, K. 2000. Slaves, Masters, and the Art of Authority in Plautine Comedy. Princeton, NJ.

McKeown, N. 2011. Resistance among Chattel Slaves in the Ancient Greek World. In Bradley - Cartledge 2011, 153-75.

Millett, P. 2007. Aristotle and Slavery in Athens. $G \& R B S$ 54: 178-209.

Nikolsky, B. 2011. Slavery and Freedom in Euripides' Cyclops. In AlstonHall - Proffitt 2011, 121-51. 


\section{Slave networks in Menander}

Osborne, R. 1991. The Potential Mobility of Human Populations. OJA 10: 231-52.

Patterson, O. 1982. Slavery and Social Death: A Comparative Study. Cambridge, Mass.

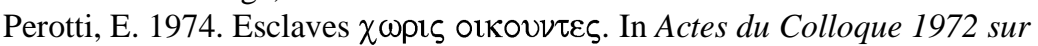
l'esclavage, 47-56. Paris.

Proffitt, L. 2011. Family, Slavery and Subversion in Menander's Epitrepontes. In Alston - Hall - Proffitt 2011, 152-74.

Rabinowitz, N. S. 1998. Slaves with Slaves: Women and Class in Euripidean Tragedy. In Joshel, S. R. - Murnaghan, S. (eds). Women and Slaves in Greco-Roman Culture: Differential Equations, 56-68. London - New York.

Schmitz, W. 2012. 'Sklavenfamilien' im archaischen und klassischen Griechenland. In Heinen, H. (ed.). Kindersklaven - Sklavenkinder: Schicksale zwischen Zuneigung und Ausbeutung in der Antike und im interkulturellen Vergleich, 63-102. Stuttgart.

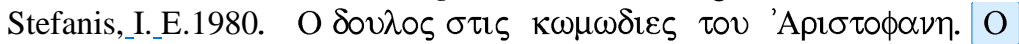

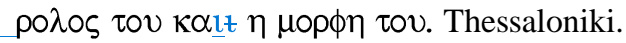

Thalmann, W. G. 2007. Despotic Authority, Fear, and Ideology of Slavery. In Serghidou, A. (ed.). Fear of Slaves - Fear of Enslavement in the Ancient Mediterranean_ Peur de l'esclave - Peur de l'esclavage en Méditerranée ancienne, 193-205. Besançon.

Traill, J. S. 1975. The Political Organization of Attica: A Study of the Demes, Trittyes, and Phylai, and Their Representation in the Athenian Council. Hesperia supplement 14.

Vlassopoulos, K. 2007a. Free Spaces: Identity, Experience and Democracy in Classical Athens. $C Q$ 57: 33-52.

Vlassopoulos, K. 2007b. Beyond and Below the Polis: Networks, Associations, and the Writing of Greek History. Mediterranean Historical Review 22.1: 11-22.

Vlassopoulos, K. 2009. Slavery, Freedom and Citizenship in Classical Athens: Beyond a Legalistic Approach. In Geary - Vlassopoulos 2009, 347-63.

Vlassopoulos, K. 2010. Athenian Slave Names and Athenian Social History. ZPE 175:113-44. 


\section{Eftychia BATHRELLOU}

Vlassopoulos, K. 2011. Greek Slavery: From Domination to Slavery and Back Again. JHS 131: 115-30.

Wiles, D. 1988. Greek Theatre and the Legitimation of Slavery. In Archer, L. (ed.). Slavery and Other Forms of Unfree Labour, 53-67. London.

Zimmermann, B. 2005. Sklaven im griechischen Drama. In Herrmann-Otto, E. (ed.). Unfreie Arbeits- und Lebensverhältnisse von der Antike bis in die Gegenwart: Eine Einführung, 20-34. Hildesheim. 